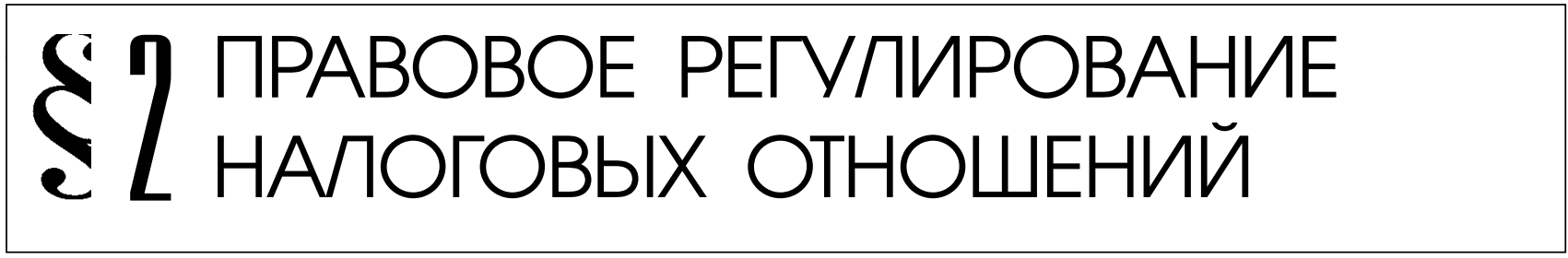

А.А. Печёнкина

\title{
О ПРАВОВОЙ ПРИРОДЕ ВОЗНИКНОВЕНИЯ И ПРЕКРАЩЕНИЯ ОБЯЗАННОСТИ ПО УПЛАТЕ НАЛОГА
}

\begin{abstract}
Аннотация: В статье рассмотрены основания возникновения и прекращения обязанности по уплате налога. Акцентируется внимание на том, что термин «объект налогообложения» в Налоговом кодексе Российской Федерации используется в значении "предмет налога». Законодательство о налогах и сборах, закрепляя понятие объекта налогообложения в $\mathrm{cm}$. 38 НК РФ, ограничивается простым их перечислением, выделяя операции по реализации товаров (работ, услуг), имущества, прибыли, дохода, стоимости реализованных товаров (выполненных работ, оказанных услуг) и иных объектов, имеющих стоимостную, количественную или физическую характеристики, с наличием которых у налогоплательщика законодательство о налогах и сборах связывает возникновение обязанности по уплате налога. Причина допущенной неточности в том, что законодатель не выделил в качестве отдельного, самостоятельного элемента предмет налога, а признаки предмета налога придал объекту. Анализ Налогового кодекса РФ позволяет утверждать, что в нем произошло фактическое совмещение таких понятий, как объект и предмет налога. В статье рассматривается соотношение понятий «объект налога» и «предмет налога». Проанализирована налогообразующая связь между налогоплательщиком и предметом налога. С учетом анализа существующих точек зрения ученых-юристов, анализа норм Налогового кодекса РФ выдвигаются предложения по совершенствованию налогового законодательства. Отсутствие в законодательстве РФ развернутой дефиниции понятия "объект налога», а также соответствие категорий, выделенных законодателем в качестве объектов налогообложения, критериям «предмета налога» позволяет говорить о следующем: в п. $1 \mathrm{~cm}$. 38 НК РФ термин «объект налогообложения» используется в значении «предмет налога». Далее, наличие объекта каждого конкретного налога, необходимого для возникновения обязанности по уплате налога, будет зависеть от юридической связи «предмета» с лицом, уплачивающим налог.
\end{abstract}

Ключевые слова: обязанность, объект налога, предмет налога, юридические факты, налогообразующая связь, публичные финансы, действия, события, налогоплательщик, налог.

бязанность по уплате налога закреплена в Конституции Российской Федерации как одна из основных обязанностей личности (ст. 57 Конституции РФ). Сущность этой обязанности раскрывается в ее содержании, в особенностях налога как публичного платежа. Консти- туционное закрепление обязанности по уплате налогов как одного из важнейших элементов правового статуса личности характерно и для подавляющего большинства зарубежных стран. Исключение составляют государства, экономика которых организована по социалистическому типу, 
что исключает приоритет налогов при формировании публичных финансов.

$\mathrm{K}$ онечно, налог является не единственным, но в большинстве государств основным источником их дохода. Однако ни в коей мере нельзя рассматривать налог только как средство для содержания аппарата государства и покрытия расходов, непременно возникающих в ходе реализации им своих функций, поскольку налог наряду с этим является также и инструментом перераспределения денежных средств в обществе.

Бурное развитие налоговых отношений требует определенного правового регулирования. Весь процесс налогообложения осуществляется и регулируется государством посредством издания нормативных правовых актов и, соответственно, всегда имеет правовую форму.

С юридической точки зрения, формы осуществления любой человеческой деятельности делятся на правовую (т.е. урегулированную нормами права) и не правовую (соответственно неурегулированную нормами права). Для первой характерно то, что она всегда влечет за собой четко выраженные юридические последствия, вторая же прямых правовых последствий не имеет. Очевидно, что уплата налога может быть осуществлена только в правовой форме в процессе действия права, которое традиционно рассматривается как часть более общего понятия механизма правового регулирования.

Отношения по уплате налогов протекают в рамках правовых отношений, устанавливаемых государством. Принято считать, что возникновение и реализация любого правового отношения происходят под воздействием определенных юридических фактов - жизненных обстоятельств, вызывающих в соответствии с нормами пра- ва наступление тех или иных правовых последствий - возникновение, изменение или прекращение правового отношения ${ }^{1}$. Г.Ф. Шершеневич отмечал, что под юридическими фактами понимаются «такие обстоятельства, с которыми нормы права связывают определенные юридические последствия» ${ }^{2}$. По словам А.Т. Шаукенова, юридические факты выступают в качестве своеобразного «шарнира», обеспечивающего переход от общей модели прав и обязанностей, закрепленных в юридической норме, к конкретной, выраженной в правоотношении ${ }^{3}$. В этой связи наиболееудачным является определение юридического факта, предложенное В.С. Нерсесянцем: «Юридические факты - это факты (фактические обстоятельства), имеющие согласно закону юридическое значение в качестве правового основания (условия), необходимого для реализации нормы права»4.

Подробный анализ юридических фактов в разрезе налоговых правоотношений был проведен А.В. Чуркиным ${ }^{5}$ Им выделяются следующие разновидности налоговозначимых юридических фактов: юридические поступки, действия, события и состояния.

Безусловно, что только правомерные действия могут явиться основанием воз-

\footnotetext{
1 Алексеев С.С. Проблемы теории права. Свердловск, 1972. С. 341-370; Исаков В.Б. Юридические факты в советском праве. М., 1984. С. 10.

2 Шершеневич Г.Ф. Общая теория права Том I. Философия права. Часть теоретическая. Рига: Давидъ Гликсманъ, 1924. С. 623.

3 Шаукенов А.Т. Налоговое обязательство в Республики Казахстан (вопросы теории и практики). Дисс. ... канд. юрид наук: 12.00.02. - Алматы, 2007.

4 Нерсесянц В.С. Общая теория государства и права. M., 1999. C. 506.

5 Чуркин А.В. Объект налогообложения: правовые характеристики: учеб. пособие. / А.В. Чуркин. - М.: Юристь, 2003. С. 46-59.
} 
никновения обязанности по уплате налога. Основной отличительный признак юридических поступков заключается в том, что они не направлены непосредственно на возникновение правовых последствий, но имеют правовое значение. Так, например, коммерческая организация, получая прибыль, не преследует цели уплатить с нее соответствующий налог, тем не менее, данная обязанность возникает независимо от ее воли в силу указаний главы 25 НК РФ. Под состоянием в налоговой сфере для целей налогообложения, например налогом на имущество, понимается право владения, пользования, распоряжения, доверительного управления недвижимым имуществом.

Согласно п. 1 ст. 44 НК РФ обязанность по уплате налога возникает, изменяется и прекращается при наличии оснований, установленных законодательством о налогах и сборах. Специфика налогового права накладывает существенные ограничения на систему юридических фактов. В соответствии с п. 3 ст. 3 НК РФ налоги должны иметь экономическое основание. Иначе говоря, их начисление должно происходить исходя из фактов и состояний экономической деятельности налогоплательщика, а не его социального статуса и иных подобных критериев. В этом плане абсолютно верным является положение п. 1 ст. 38 НК РФ, в соответствии с которым только обстоятельства, имеющие стоимостную, количественную или физическую характеристику могут лежать в основе возникновения обязанности по уплате налога.

Следует согласиться с Д.В. Винницким, который отмечает, что положения п. 1 ст. 44 НК РФ необходимо понимать с учетом системных связей данной правовой нормы со статьей 38 НК РФ, согласно которой именно объект налогообложения по- нимается как экономическое основание, обуславливающее возникновение конкретной обязанности налогоплательщика (плательщика сбора) по уплате налога 6 .

Однако, законодательство о налогах и сборах, закрепляя понятие объекта налогообложения в ст. 38 НК РФ, ограничивается простым их перечислением, выделяя операции по реализации товаров (работ, услуг), имущества, прибыли, дохода, стоимости реализованных товаров (выполненных работ, оказанных услуг) и иных объектов, имеющих стоимостную, количественную или физическую характеристики, с наличием которых у налогоплательщика законодательство о налогах и сборах связывает возникновение обязанности по уплате налога.

Причина допущенной неточности в том, что законодатель не выделил в качестве отдельного, самостоятельного элемента предмет налога, а признаки предмета налога придал объекту. Анализ Налогового кодекса РФ позволяет утверждать, что в нем произошло фактическое совмещение таких понятий, как объект и предмет налога.

В современной научной литературе, наиболее точное определение объекта налогообложения с отражением всех его существенных признаков было дано С.Г. Пепеляевым. В частности, он пишет: «Объект налогообложения - это те юридические факты (действия, события, состояния), которые обусловливают обязанность субъекта заплатить налог... Понятию объект налогообложения близок по значению термин предмет налогообложения, который обозначает признаки фактического (неюриди-

\footnotetext{
6 Финансовое право Российской Федерации. / Отв. ред. М.В. Карасева. 2-е изд., перераб. и доп. М.: Юристъ, 2006. С. 342 (автор главы 19 - Д. В. Винницкий).
} 
ческого) характера, которые обосновывают взимание соответствующего налога» 7 .

Заметим, что прежде чем ввести тот или иной налог, государство в первую очередь ищет и находит тот предмет материального мира, который стал бы основой для налогообложения, материальным основанием налога. Таковыми на сегодняшний день являются земля, недвижимость, прибыль и др. Но выбор и определение предмета налога являются лишь первым шагом на пути установления налога. Вслед за этим требуется выявить юридическую связь между субъектом налога и предметом налога.

Интересно отметить, что на наличие такой связи прямо или косвенно указывают большинство авторов работ по вопросам налогообложения или налогового права. По мнению Е.В. Порохова, такая связь должна быть тесной и устойчивой, в противном случае указанная обязанность не возникнет $^{8}$. Устойчивая правовая связь предполагает отношения собственности или иные вещные отношения налогоплательщика, указывающие на принадлежность налогоплательщику предмета налога.

Конечно же, предмет налога сам по себе не порождает налоговых последствий, тогда как определенное юридическое состояние субъекта налога по отношению к нему приводит к возникновению обязанности по уплате налога. Факт же наличия у налогоплательщика налогообразующей связи с предметом налога, проявляющийся в каком-либо действии налогоплательщика, событии или состоянии следует рассматривать в качестве объекта налога и одно-

7 Пепеляев С.Г. Как определить объект налогообложения // В кн.: Ваш налоговый адвокат. Советы юристов: Сборник статей. Вып.1. - М.: ФБК-ПРЕСС, 1997. С. 29. 8 Порохов Е.В. Теория налоговых обязательств: Учебное пособие. Алматы, 2001. С. 98-99. временно в качестве основания возникновения обязанности по уплате налога.

Неудачным определение объекта налога, данное в ст. 38 НК РФ, представляется в силу возможности введения налогов на вмененный доход, обязанность по уплате которых не зависит от факта наличия либо отсутствия у налогоплательщика какого-либо объекта. Основанием уплаты подобных налогов является неопровержимая презумпция. По словам Д.М. Щекина, применение презумпций для установления объекта налога связано с трудностью их обнаружения. В этом случае законодатель по внешним признакам, которые легко установить, делает вывод о наличии у налогоплательщика дохода, подлежащего налогообложению 9 .

Соответственно налогоплательщик обязан по истечении налогового периода уплачивать ЕНВД независимо от фактического получения дохода. Из чего следует, что ст. 346.29 НК РФ противоречит ст. 38 НК РФ. Данное обстоятельство негативно сказывается на системности налогового права и выделении в нем общей части, как совокупности норм, устанавливающих общие термины и понятия для всей отрасли.

Также ст. 38 НК РФ в качестве ключевого момента возникновения обязанности по уплате налога вводит понятие «наличие». Однако ни в одной норме законодательства о налогах и сборах указанный термин не расшифровывается. Также отсутствует его правовое наполнение и в нормах иных отраслей права. Например, транспортное средство может находиться у гражданина на праве собственности, временного пользования, владения и т.д.

\footnotetext{
9 Щекин Д.М. Юридические презумпции в налоговом праве: учебное пособие / Д.М. Щекин: под ред. С.Г. Пепеляева. - М.: Академический правовой университет, 2002. С. 165.
} 
Однако п. 1 ст. 357 НК РФ обязанности налогоплательщика возлагает лишь на тех лиц, на которых зарегистрированы транспортные средства. Соответственно термин «наличие» не может применяться для целей налогообложения также и в его общеупотребительном значении.

Нормативное определение объекта налогообложения является неудачным в силу использования недостаточно определенных терминов, выпадения объектов, построенных с использованием правовых презумпций, отсутствия классифицирующих признаков.

В связи с этим представляется оправданным рекомендовать изложить п. 1 ст. 38 НК РФ в следующей редакции: «Объект налога - это юридический факт (действие, событие, состояние), возникающий в отношении предмета налога, являющийся основанием возникновения обязанности по уплате налога, обусловленный получением доходов, приобретением имущества и обладанием им, осуществлением расходов, связанных с потреблением и указывающий на появление у налогоплательщика источника налога», а «предмет налога объект материального мира, способный быть источником экономической выгоды в результате воздействия на него налогоплательщика, или в связи с его принадлежностью ему, с наличием которого закон связывает возникновение обязанности по уплате налога» и что «каждый налог имеет самостоятельный объект и предмет налога, определяемый в соответствии с частью второй настоящего Кодекса и с учетом положений настоящей статьи.».

Прекращение обязанности по уплате налога является завершающим этапом ее существования. Момент прекращения обязанности по уплате налога определен наступлением конкретных юридических фактов, которые закрепляются в законодательстве в качестве оснований соответствующего правового результата. Исполнение обязанности по уплате налога является основным правопрекращающим фактом.

Надлежащее исполнение обязанности по уплате налога является главным желаемым со стороны государства основанием ее прекращения, влекущим за собой достижение государством поставленной цели формирование доходов государственного бюджета.

Для государственных органов, выступающих в налоговых правоотношениях от имени государства, право взимания налога является компетенционной обязанностью. Соответственно, в налоговом праве существует ограниченный перечень оснований прекращения обязанности по уплате налога. Называя конкретные основания (п. 3 ст. 44 НК РФ), прекращающие данную обязанность (уплата налога, смерть налогоплательщика или объявление его умершим, ликвидация организации-налогоплательщика), законодатель предусматривает также возможность наличия в актах законодательства о налогах и (или) сборах иных оснований, по которым обязанность по уплате налога (сбора) может считаться прекращенной. В действующем законодательстве, например, таким основанием является списание недоимки и задолженности по пеням и штрафам, признанных безнадежными к взысканию (ст. 59 НК РФ), уплата налога за налогоплательщика его поручителем в порядке ст. 74 НК РФ.

Вполне традиционным основанием прекращения обязанности по уплате налога у физического лица является его смерть. Данный юридический факт с безусловностью влечет за собой прекраще- 
ние обязанности по уплате налога в полном объеме. Аналогичным основанием прекращения обязанности по уплате налога, но уже по отношению к юридическим лицам, выступает юридический факт их ликвидации. Ликвидацию юридического лица также следует отнести к безусловному основанию прекращения обязанности по уплате налога, т.к. ликвидация любого юридического лица представляет собой регистрацию прекращения его деятельности без перехода прав и обязанностей в порядке правопреемства к другим лицам.

Следует заметить, что смерть физического лица традиционно рассматривается способом погашения частно-правового обязательства, но за одним исключением: если обязательство умершего физического лица, являвшегося в обязательстве должником, не носит строго личного характера, и у умершего лица имеется наследник, то в силу принципа универсального правопреемства на наследника возлагается исполнение обязанностей, возникших из обязательства наследодателя. При объявлении гражданина умершим суд исходит из предположения его смерти. Вместе с тем, правовые последствия объявления гражданина умершим в данной связи аналогичны правовым последствиям (естественной) смерти гражданина (в частности вступившее в силу решение суда об объявлении гражданина умершим является основанием для внесения записи о смерти этого гражданина в книгу записей актов гражданского состояния), в том числе в отношении обязанности по уплате налога.

По общему правилу, на наследника (наследников) налогоплательщика не возлагается обязанность по уплате налогов наследодателя, однако в отношении уплаты некоторых налогов законодате- лем сделано исключение: задолженность по транспортному налогу, налогу на имущество физических лиц и земельному налогу умершего лица либо лица, объявленного умершим, погашается наследниками в пределах стоимости наследственного имущества в порядке, установленном гражданским законодательством Российской Федерации для оплаты наследниками долгов наследодателя.

Смерть физического лица при отсутствии у него наследников или отказе наследников от наследства является юридическим фактом, в результате которого неисполненная обязанность по уплате налога этого лица прекращается. Наличие наследников (при условии принятия ими наследства) вовлекает их в процесс исполнения неисполненной наследодателем обязанности по уплате налога, а сами наследники рассматриваются в этом случае третьими лицами, так как обязанность по уплате ими налога обусловлена не возникновением у них объекта налога, а принципом универсального правопреемства.

Таким образом, смерть гражданина или объявление его умершим влекут прекращение обязанности по уплате налога, за исключением обязанности погасить задолженность по поимущественным налогам, которая возлагается на наследников. Более того, как уже отмечалось ранее, смерть физического лица относится к безусловному основанию, то есть основанию, прекращающему обязанность вне зависимости от воли управомоченного лица.

Наиболее распространенная ситуация прекращения обязанности по уплате налога - это уплата налога, то есть непосредственное исполнение самой обязанности по уплате налога. Конституционное требование уплачивать соответствующие налоги конкретизируется в Налоговом 
кодексе Российской Федерации, который на сегодняшний день является, по сути, единственным федеральным актом законодательства о налогах и сборах. Исполнение данной обязанности является первоочередной обязанностью по отношению к иным имущественным обязанностям налогоплательщика и определяет развитие последующих налоговых правоотношений. Сущность исполнения обязанности по уплате налога сводится к тому, чтобы государство получило в свое фактическое обладание уплаченные в виде налогов денежные средства и чтобы одновременно у государства возникло бессрочное и безусловное право собственности на эти деньги. Поэтому моментом исполнения обязанности по уплате налога следует признавать момент совершения субъектом налога (или его представителем) всех истребуемых от него налоговым законом действий, направленных в конечном итоге на уплату налога государству. Надлежащее исполнение обязанности по уплате налога является одним из проявлений общеправового принципа законности, предполагающего соответствие между действием налогоплательщика и его обязанностью уплаты налога, совершение им действий в полном соответствии с требованиями закона. Но при этом нельзя забывать и о надлежащем поведении уполномоченных законом налоговых органов.

Прекращение обязанности по уплате налога означает, что права и обязанности, вытекающие из данной обязанности, более не связывают налогоплательщика и государство. Государство больше не имеет права предъявлять к налогоплательщику каких-либо требований, опираясь на конституционную обязанность уплаты налога. Но тогда, как же быть с теми налогами, обязанность по уплате которых возникает вновь, после исполнения данной обязанности. Например, большинство поимущественных налогов (налог на имущество, транспортный налог, земельный налог) относятся к периодически возникающим налогам. Независимо от того, меняется состав предмета поимущественного налогообложения или нет, обязанность по уплате налога возникает периодически (как правило, ежегодно) и соответственно прекращается в связи с уплатой налога.

Тогда достаточно спорным является то, что уплата налога является основанием прекращения обязанности по уплате налога, полагаем, что здесь можно говорить о временном прекращении обязанности по уплате налога в связи с уплатой налога, ведь с момента наступления нового налогового периода обязанность по уплате налога снова возникает. До тех пор пока между налогоплательщиком и предметом налога будет присутствовать налогообразующая связь ${ }^{10}$, обязанность по уплате налога будет возникать. Только исчезновение объекта налога как юридического факта будет являться основой для прекращения обязанности по уплате налога.

В то же время нельзя исключать и другие основания прекращения обязанности по уплате налога, но все иные основания прекращения обязанности по уплате налога должны применяться крайне осторожно и быть не более чем редким исключением из общего правила. Ведь налог призван удовлетворять, прежде всего, интересы всего общества и государства.

\footnotetext{
10 Именно эта правовая связь налогоплательщика с предметом налога, закрепленная в норме права, переводит предмет налога в объект налога - юридический факт, который влечет у налогоплательщика обязанность по уплате налога.
} 


\section{Библиография:}

1. Алексеев С.С. Проблемы теории права. Свердловск, 1972. С. 341-370.

2. Исаков В.Б. Юридические факты в советском праве. М., 1984. С. 10.

3. Нерсесянц В.С. Общая теория государства и права. М., 1999. С. 506.

4. Пепеляев С.Г. Как определить объект налогообложения // В кн.: Ваш налоговый адвокат. Советы юристов: Сборник статей. Вып.1. - М.: ФБК-ПРЕСС, 1997. С. 29.

5. Порохов Е.В. Теория налоговых обязательств: Учебное пособие. Алматы, 2001. С. 9899.

6. Финансовое право Российской Федерации. / Отв. ред. М.В. Карасева. 2-е изд., перераб. и доп. М.: Юристъ, 2006. С. 342 (автор главы 19-Д. В. Винницкий).

7. Чуркин А.В. Объект налогообложения: правовые характеристики: учеб. пособие. / А.В. Чуркин. - М.: Юристъ, 2003. С. 46-59.

8. Шаукенов А.Т. Налоговое обязательство в Республики Казахстан (вопросы теории и практики). Дисс. ... канд. юрид наук: 12.00.02. - Алматы, 2007.

9. Щекин Д.М. Юридические презумпции в налоговом праве: учебное пособие / Д.М. Щекин: под ред. С.Г. Пепеляева. - М.: Академический правовой университет, 2002. С. 165.

10. Шершеневич Г.Ф. Общая теория права Том I. Философия права. Часть теоретическая. Рига: Давидъ Гликсманъ, 1924. С. 623.

11. Кинсбурская В.А. Ответственность налогоплательщика за непредставление налоговой декларации: спорные вопросы правоприменительной практики // NB: Финансовое право и управление. - 2013. - 1. - C. 17-48. URL: http://www.e-notabene.ru/flc/ article_558.html

12. Ефремова Т.А. Налоговое администрирование в России: предпосылки становления и особенности функционирования // NB: Финансовое право и управление. - 2013. 2. - C. 1-23. URL: http://www.e-notabene.ru/flc/article_622.html

13. Аринин Е.А. Теоретические аспекты организационно-правового механизма налогообложения в Российской Федерации. // NB: Финансовое право и управление. -2013. - 4. - C. 1-29. URL: http://www.e-notabene.ru/flc/article_855.html

14. Агузарова Ф.С. Некоторые вопросы модернизации налоговой системы Российской Федерации // NB: Финансовое право и управление. - 2013. - 2. - С. 24-44. URL: http://www.e-notabene.ru/flc/article_629.html

15. С.И. Сиражудинова Информационная помощь налогоплательщику как способ поддержания налоговой дисциплины // Налоги и налогообложение. - 2013. - 1. C. 68-74. DOI: 10.7256/1812-8688.2013.01.7.

16. С.В. Барташевич Налоговое обязательство: понятие, место в системе налогово-правовых явлений и отграничение от смежных категорий налогового права // Налоги и налогообложение. - 2013. - 2. - C. 121-127. DOI: 10.7256/1812-8688.2013.02.4.

17. Напсо М.Б. Исполнение налоговой обязанности: к вопросу о содержании формулировки презумпции добровольности внесения налога // Налоги и налогообложение. 2013. - 4. - C. 263-268. DOI: 10.7256/1812-8688.2013.4.7913.

18. Ю. А. Артемьева Особенности правового статуса налогоплательщиков // Налоги и налогообложение. - 2012. - 2. - С. 13-18. 
19. Акопджанова М.О.. Формирование современного законодательства Российской Федерации об уголовной ответственности за преступления против установленного порядка уплаты налогов и сборов. // Право и политика. - 2013. - № 8. - С. 1022-1026. DOI: 10.7256/1811-9018.2013.8.8390.

\section{References:}

1. Alekseev S.S. Problemy teorii prava. Sverdlovsk, 1972. S. 341-370.

2. Isakov V.B. Yuridicheskie fakty v sovetskom prave. M., 1984. S. 10.

3. Nersesyants V.S. Obshchaya teoriya gosudarstva i prava. M., 1999. S. 506.

4. Pepelyaev S.G. Kak opredelit' ob"ekt nalogooblozheniya // V kn.: Vash nalogovyi advokat. Sovety yuristov: Sbornik statei. Vyp.1. — M.: FBK-PRESS, 1997. S. 29.

5. Porokhov E.V. Teoriya nalogovykh obyazatel'stv: Uchebnoe posobie. Almaty, 2001. S. 98-99.

6. Finansovoe pravo Rossiiskoi Federatsii. / Otv. red. M.V. Karaseva. 2-e izd., pererab. i dop. M.: Yurist", 2006. S. 342 (avtor glavy 19-D. V. Vinnitskii).

7. Churkin A.V. Ob"ekt nalogooblozheniya: pravovye kharakteristiki: ucheb. posobie. / A.V. Churkin. - M.: Yurist", 2003. S. 46-59.

8. Shaukenov A.T. Nalogovoe obyazatel'stvo v Respubliki Kazakhstan (voprosy teorii i praktiki). Diss. ... kand. yurid nauk: 12.00.02. — Almaty, 2007.

9. Shchekin D.M. Yuridicheskie prezumptsii $\mathrm{v}$ nalogovom prave: uchebnoe posobie / D.M. Shchekin: pod red. S.G. Pepelyaeva. - M.: Akademicheskii pravovoi universitet, 2002. S. 165.

10. Shershenevich G.F. Obshchaya teoriya prava Tom I. Filosofiya prava. Chast' teoreticheskaya. Riga: David" Gliksman", 1924. S. 623.

11. Kinsburskaya V.A. Otvetstvennost' nalogoplatel'shchika za nepredstavlenie nalogovoi deklaratsii: spornye voprosy pravoprimenitel'noi praktiki // NB: Finansovoe pravo i upravlenie. - 2013. - 1. - C. 17-48. URL: http://www.e-notabene.ru/flc/article_558.html

12. Efremova T.A. Nalogovoe administrirovanie v Rossii: predposylki stanovleniya i osobennosti funktsionirovaniya // NB: Finansovoe pravo i upravlenie. - 2013. - 2. - C. 1-23. URL: http://www.e-notabene.ru/flc/article_622.html

13. Arinin E.A. Teoreticheskie aspekty organizatsionno-pravovogo mekhanizma nalogooblozheniya v Rossiiskoi Federatsii. // NB: Finansovoe pravo i upravlenie. - 2013. - 4. C. 1-29. URL: http://www.e-notabene.ru/flc/article_855.html

14. Aguzarova F.S. Nekotorye voprosy modernizatsii nalogovoi sistemy Rossiiskoi Federatsii // NB: Finansovoe pravo i upravlenie. - 2013. - 2. - C. 24-44. URL: http://www.e-notabene. $\mathrm{ru} / \mathrm{flc} /$ article_629.html

15. S.I. Sirazhudinova Informatsionnaya pomoshch' nalogoplatel'shchiku kak sposob podderzhaniya nalogovoi distsipliny // Nalogi i nalogooblozhenie. - 2013. - 1. - C. 68-74. DOI: 10.7256/1812-8688.2013.01.7.

16. S.V. Bartashevich Nalogovoe obyazatel'stvo: ponyatie, mesto $v$ sisteme nalogovo-pravovykh yavlenii i otgranichenie ot smezhnykh kategorii nalogovogo prava // Nalogi i nalogooblozhenie. - 2013. - 2. - C. 121-127. DOI: 10.7256/1812-8688.2013.02.4. 
DOI: $10.7256 / 1812-8688.2014 .2 .11003$

При цитировании этой статьи сноска на dоі обязательна

\section{Правовое регулирование налоговых отношений}

17. Napso M.B. Ispolnenie nalogovoi obyazannosti: k voprosu o soderzhanii formulirovki prezumptsii dobrovol'nosti vneseniya naloga // Nalogi i nalogooblozhenie. - 2013. - 4. C. 263-268. DOI: 10.7256/1812-8688.2013.4.7913.

18. Yu. A. Artem'eva Osobennosti pravovogo statusa nalogoplatel'shchikov // Nalogi i nalogooblozhenie. - 2012. - 2. - C. 13-18.

19. Akopdzhanova M.O.. Formirovanie sovremennogo zakonodatel'stva Rossiiskoi Federatsii ob ugolovnoi otvetstvennosti za prestupleniya protiv ustanovlennogo poryadka uplaty nalogov i sborov. // Pravo i politika. — 2013. — № 8. - C. 1022-1026. DOI: 10.7256/18119018.2013.8.8390. 